\title{
Pengaruh Kualitas Produk dan Persepsi Harga Terhadap Kepuasan Konsumen Studio Fotografi Calista Yogyakarta
}

\author{
Dwi Retno \\ Universitas Negeri Medan; Jalan Willem Iskandar Pasar V Medan Estate \\ E-mail: dwiretnosiregar92@gmail.com
}

\begin{abstract}
ABSTRAK
Penelitian ini bertujuan untuk menguji pengaruh kualitas produk dan persepsi harga terhadap kepuasan konsumen studio Calista Yogyakarta. Penelitian ini dilakukan di studio Calista Kota Yogyakarta dengan menyurvei 100 responden. Teknik pengambilan sampel dengan metode survei, menggunakan kuesioner dengan teknik. Metode analisis menggunakan analisis regresi berganda. Hasil penelitian ini, menemukan adanya pengaruh positif dan signifikan antara kualitas produk dan persepsi harga terhadap kepuasan konsumen. Kualitas poduk berpengaruh terhadap kepuasan konsumen dengan tingkat kepuasan 10,568 dengan signifikan sebesar 0,000 kurang dari $5 \%(0,000<0,050)$ dan persepsi harga terhadap kepuasan konsumen 1,642 dengan signifikan sebesar 0,104 lebih dari $5 \%(0,104>0,050)$. Persepsi harga tidak signifikan karena, apabila suatu produk memiliki kualitas bagus maka secara langsung konsumen tidak mempermasalahkan harga dan tidak memengaruhi kepuasan konsumen.
\end{abstract}

Kata Kunci: kualitas produk, persepsi harga, kepuasan konsumen

Effect of Product Quality and Price Perception on Consumer Satisfaction at Calista Yogyakarta Photography Studio

\section{ABSTRACT}

This study aims to examine the effect of product quality and price perceptions on consumer satisfaction at the Yogyakarta Calista studio. This research was conducted in the Calista studio of Yogyakarta City by surveying 100 respondents. The sampling technique using the survey method, using a questionnaire with techniques. The method of analysis uses multiple regression analysis. The results of this study found a positive and significant effect between product quality and price perception on consumer satisfaction. Product quality has an effect on consumer satisfaction with a level of satisfaction of 10,568 with a significance of 0,000 less than $5 \%(0,000<0,050)$ and a perception of price on satisfaction of 1,642 with a significance of 0,104 more than $5 \%(0,104>0,050)$. Perception of the price is not significant because if the product has a price issue and does not affect customer satisfaction. Good quality, then directly consumers are not.

Keywords: product quality, perception of prices, consumer satisfaction

\section{PENDAHULUAN}

Kota Yogyakarta adalah salah satu kota yang mengikuti perkembangan teknologi masa kini, terutama dalam bidang perkembangan bisnis jasa fotografi. Bisnis studio fotografi berkembang pesat sejak sebelum era digital hingga era modern seiring perkembangan teknologi saat ini. Dengan demikian, perkembangan 
jasa juga fotografi di Yogyakarta dengan proses studio fotografi telah banyak didirikan dengan memberikan kualitas foto yang beragam, sehingga para pesaing harus mampu mengikuti perkembangan zaman dari tahun ke tahun, supaya konsumen semakin mudah memilih studio fotografi yang sesuai keinginan konsumen.

Di era modern ini telah banyak kemajuan dan perubahan yang terjadi dalam dunia bisnis. Adapun perubahan yang terjadi ditandai dengan pola pikir masyarakat yang berkembang, kemajuan teknologi, dan gaya hidup yang tidak lepas dari pengaruh globalisasi. Pengaruh dari perkembangan tersebut ditandai dengan banyaknya produk yang menawarkan berbagai macam kelebihan pada suatu produk perusahaan. Bagi perusahaan lain, hal ini merupakan suatu bentuk ancaman karena semakin banyak produk yang ditawarkan maka, semakin ketat pula persaingan yang terjadi dalam dunia bisnis.

Tujuan untuk menciptakan dan mempertahankan konsumen harus dipenuhi oleh perusahaan untuk mencapai kesuksesan dalam persaingan dengan cara setiap perusahaan harus mampu berupaya untuk menghasilkan dan menyampaikan produk yang diinginkan konsumen dengan harga yang pantas. Hal tersebut membuat setiap perusahaan harus mampu memahami perilaku konsumen pada pasar sasarannya karena kelangsungan hidup perusahaan tersebut sangat bergantung pada perilaku konsumen.

Perusahaan seharusnya menyusun strategi dan program yang tepat dalam rangka memanfaatkan peluang yang ada dan mengungguli para pesaingnya sehingga perusahaan dapat menciptakan perilaku konsumen yang tujuannya yaitu kepuasan konsumen. Hal ini dapat dilihat dari pendapat Tjiptono (1997:24) pada dasarnya tujuan dari suatu bisnis yaitu untuk menciptakan para konsumen merasa puas.

Studio Calista merupakan salah satu perusahaan bidang fotografi yang bertahan dan berkembang hingga sekarang ini, dan masih mampu mempertahankan dan mengembangkan kualitas produk. Selain itu, studio Calista juga tetap memberikan harga yang sesuai dengan kualitas produk. Studio Calista juga masih mempertahankan konsumen dan juga tetap memberikan kualitas produk, dengan tujuan mempertahankan kepuasan konsumen sehingga tetap loyal terhadap perusahaan.

Menurut Kotler dan Amstrong (2001:73), harga merupakan sejumlah uang yang dibebankan atas suatu produk atau jumlah dari seluruh nilai yang ditukarkan oleh konsumen atau manfaat karena menggunakan produk atau jasa tersebut. Salah satu faktor yang harus diperhatikan untuk meraih kepuasan konsumen adalah harga karena harga yang ditawarkan oleh sebuah perusahaan merupakan relatif harga yang terjangkau bagi konsumen. Dalam hal ini, konsumen merasa puas apabila harga dari suatu produk yang ditawarkan oleh perusahaan sesuai dengan manfaat 
yang didapatkan oleh konsumen, karena harga merupakan nilai suatu produk yang dikeluarkan, dalam pertukaran untuk mendapatkan produk (Basu Swastha, 2013:72). Dengan kata lain, harga merupakan apa yang dibayarkan konsumen untuk mendapatkan sesuatu.

Kualitas produk merupakan salah satu senjata strategis bagi sebuah perusahaan, yang pontensial untuk mengalahkan pesaing-pesaing (Kotler \& Amstrong, 2009). Dengan adanya kualitas produk yang baik dan didukung dengan strategi penetapan harga yang mampu bersaing tentunya juga akan memengaruhi suatu produk, yang nantinya akan menimbulkan rasa kepuasan tersendiri bagi para konsumen terhadap suatu perusahaan. Kepuasan konsumen merupakan perasaan seseorang setelah membandingkan kinerja atau hasil yang ia rasakan dibandingkan dengan yang diharapkan (Kotler dan Keller, 2009:177).

Kepuasan konsumen perlu diperhatikan oleh perusahaan/pelaku usaha karena akan berdampak pada kinerja penjualan. Tjiptono (2014:353) menyatakan bahwa kepuasan konsumen berkontribusi pada sejumlah aspek krusial, seperti terciptanya loyalitas konsumen dan meningkatnya reputasi perusahaan.

\section{KAJIAN PUSTAKA}

\section{Kualitas Produk}

Fotografi tetap memberikan berbagai media ekspresi yang menarik dan indah di mata masyarakat. Menurut Kotler dan Keller (2009:4), produk adalah segala sesuatu yang dapat ditawarkan kepada pasar, untuk memuaskan suatu keinginan atau kebutuhan termasuk barang. Biasanya fotografi yang ditawarkan oleh perusahaan berupa barang hasil cetakan foto, beserta ide fotografi yang sesuai dengan keinginan konsumen.

Biasanya fotografi yang berkualitas memiliki manfaat dan nilai guna bagi konsumen, seperti warna cetakan foto yang dihasilkan dengan daya tahan foto yang dapat dimanfaatkan konsumen. Warna yang dihasilkan dalam fotografi merupakan kunci utama bagi konsumen untuk menentukan bahwa foto yang dimiliki adalah foto berkualitas sesuai dengan yang diharapkan. Di samping itu, warna cetak yang dihasilkan pada foto tidak mudah terkelupas, berubah warna atau rusak, serta memiliki salah satu bukti yang didapatkan dan bisa memenuhi keinginan. Berikut indikator yang digunakan untuk meneliti kualitas produk, seperti yang dikemukakan oleh David A. Garvin (1987) sebagai berikut:

a. Performance yaitu ciri-ciri pengoperasian pokok dari suatu produk inti (core product).

b. Features yaitu ciri khusus keistimewaan tambahan.

c. Reliability (kehandalan).

d. Conformance (kesesuaian dengan standar).

e. Durability (daya tahan). 
f. Serviceability yaitu kemudahan layanan atau perbaikan jika dibutuhkan.

g. Aesthetic (estetika) yaitu daya tarik produk melalui panca indera.

h. Perceived quality yaitu citra dan reputasi produk serta tanggung jawab perusahaan terhadap kedua hal tersebut.

\section{Persepsi Harga}

Menurut Petrick 2004, bahwa persepsi harga mengacu pada harga moneter (harga suatu barang yang sudah ditentukan) misalkan, harga satu paket pas foto senilai Rp35.000,00, harga tersebut merupakan harga yang relatif wajar dan sesuai bagi konsumen, karena dengan harga Rp35.000,00, konsumen berhak mendapatkan beberapa lembar foto yang sudah jadi dengan berbagai ukuran serta VCD. Harga yang sudah ditentukan merupakan harga yang wajar bagi konsumen, yang terdiri dari biaya kertas, cetak, VCD, dan upah tukang foto.

Memahami tingkah laku konsumen merupakan suatu proses/waktu pelayanan yang diberikan pihak Studio Calista kepada konsumen yang baru datang maupun yang sudah lama menunggu. Misalnya, waktu psikologis (perilaku konsumen) yaitu suatu perusahaan harus mampu memahami perilaku/tingkah laku konsumen, dalam artian setiap ada konsumen yang datang ke Studio Calista, maka pihak perusahaan secara cepat menanggapi/menayakan konsumen apa yang bisa dibantu, setiap pelayanan yang cepat bagi konsumen maka keinginan konsumen akan lebih mudah diberikan oleh pihak Studio Calista, di mana setelah konsumen sampai Studio Calista, konsumen harus mengikuti aturan yang ada yaitu, mengantre untuk mendapatkan giliran untuk berfoto, setelah itu konsumen menunggu antrean lagi untuk mendapatkan hasil cetakan foto. Konsumen tentu menghabiskan banyak waktu untuk mendapatkan sesuatu yang diinginkan, dan ini merupakan sebuah proses untuk bisa mendapatkan apa yang diinginkan oleh konsumen sehingga apa yang diinginkan oleh konsumen cepat teratasi atau terpenuhi.

\section{Kepuasan Konsumen}

Memahami tingkah laku konsumen merupakan suatu proses/waktu pelayanan yang diberikan pihak Studio Calista kepada konsumen yang baru datang maupun yang sudah lama menunggu. Misalnya waktu psikologis (perilaku konsumen) yaitu, suatu perusahaan harus mampu memahami perilaku/tingkah laku konsumen, dalam artian setiap ada konsumen yang datang ke Studio Calista, maka pihak perusahaan secara cepat menanggapi/menayakan konsumen apa yang bisa dibantu. Setiap pelayanan yang cepat kepada konsumen maka, kepuasan konsumen pun lebih cepat didapatkan. Setelah konsumen sampai di Studio Calista, konsumen harus mengikuti aturan yang ada yaitu, mengantre untuk mendapatkan giliran untuk berfoto, setelah itu konsumen menunggu antrean kembali untuk mendapatkan hasil cetakan foto. Dalam hal ini, konsumen tentu menghabiskan banyak waktu untuk mendapatkan sesuatu yang diinginkan, dan ini merupakan sebuah proses untuk bisa mendapatkan apa yang diinginkan oleh konsumen sehingga apa yang diinginkan 
oleh konsumen dapat cepat teratasi atau terpenuhi. Misalnya, saat konsumen mencetak foto; dalam proses cetak foto tentu tidak dapat secara instan sehingga, konsumen menunggu sejenak untuk bisa mendapatkan foto yang diinginkan.

\section{METODE PENELITIAN}

\section{Hasil Pengumpulan Data}

Penyebaran angket kuesioner sebanyak 110 responden, dengan memberikan angket kepada responden yang datang untuk berfoto. Pengambilan jumlah responden berjumlah 100 kuesioner, untuk menganalisis kurangnya jumlah responden, kuesioner peneliti melebihi jumlah penyebaran sebanyak 110 kuesioner.

\section{Validitas dan Reliabilitas Data}

Tabel 1. Uji Validitas

\begin{tabular}{clcccc}
\hline No & Dimensi & Item Indikator & r-Hitung & r-Tabel & Keterangan \\
\hline 1. & Kualitas & KP1 & 0,602 & 0,000 & Valid \\
& Produk & KP2 & 0,568 & 0,000 & Valid \\
& & KP3 & 0,829 & 0,000 & Valid \\
& & KP4 & 0,461 & 0,000 & Valid \\
& & KP5 & 0,570 & 0,000 & Valid \\
& & KP6 & 0,320 & 0,001 & Valid \\
& & KP7 & 0,635 & 0,000 & Valid \\
2. & Kersepsi & PH1 & 0,829 & 0,000 & Valid \\
& Harga & PH2 & 0,544 & 0,000 & Valid \\
& & PH3 & 0,763 & 0,000 & Valid \\
& & PH4 & 0,613 & 0,000 & Valid \\
& & PH5 & 0,623 & 0,000 & Valid \\
& & PH6 & 0,524 & 0,000 & Valid \\
& PH7 & 0,614 & 0,000 & Valid \\
3. Kepuasan & Puas 1 & 0,606 & 0,000 & Valid \\
& Konsumen & Puas 2 & 0,484 & 0,000 & Valid \\
& & Puas 3 & 0,678 & 0,000 & Valid \\
& Puas 4 & 0,730 & 0,000 & Valid \\
\hline
\end{tabular}

Tabel uji validitas tersebut menunjukkan bahwa indikator pertanyaan seluruh variabel dinyatakan valid, di mana nilai signifikansi pada hasil uji validitas dengan analisis bivariat lebih kecil dari 0,05 persen. 


\section{Uji Reliabilitas}

\begin{tabular}{lcc}
\hline \multicolumn{1}{c}{ Variabel } & Alfa Cronbach & Keterangan \\
\hline Kualitas Produk & 0,749 & Reliabel \\
Persepsi Harga & 0,738 & Reliabel \\
Kepuasan Konsumen & 0,739 & Reliabel \\
\hline
\end{tabular}

Tabel 2 di atas menunjukkan bahwa nilai Alfa Cronbach untuk setiap variabel di atas 0,6 persen, sehingga dapat disimpulkan bahwa seluruh variabel dinyatakan valid.

\section{Profil Demografi Responden}

Dari hasil rekapitulasi 100 kuesioner, ditemukan berbagai profil responden yang berpartisipasi memberikan penilaian dan ekspektasi terhadap pelayanan di Studio Calista.

Berdasarkan distribusi frekuensi, secara garis besar mayoritas karakteristik demografi, kategori jenis kelamin perempuan dengan persentase $60 \%$, sedangkan karakteristik demografi kategori jenis kelamin laki-laki sebesar 40\%. Adapun persentase berdasarkan usia 17-19 tahun sebanyak 54\%, dan berdasarkan pendidikan yang didominasi lulusan SMA sebanyak 54\% yang terlibat dalam penelitian ini.

\section{Karakteristik Responden Studio Calista}

Dari jenis kelamin responden, dapat dilihat bahwa dari 100 orang jumlah responden, sebanyak 40 responden atau $40 \%$ berjenis kelamin laki-laki dan 60 responden atau $60 \%$ dari 100 responden, berjenis kelamin perempuan. Berdasarkan hasil tanya jawab di lapangan/pada waktu penyebaran angket, dihasilkan bahwa segmen pasar dari studio foto ini lebih dominan pada anak muda. Sesuai dengan temuan di lapangan sewaktu penyebaran angket, bahwa kaum perempuan ditemui pada saat berfoto dan lebih banyak. Untuk memperjelas temuan ini, peneliti melakukan wawancara pada staf manajemen. Dari penjelasan narasumber dapat disimpulkan, bahwa anak muda berjenis kelamin wanita berkunjung untuk berfoto, baik foto pribadi maupun foto yang lain. Sesuai dengan pengalaman Studio Calista dari tahun ke tahun, konsumen berjenis kelamin wanita lebih banyak dibandingkan konsumen laki-laki.

\section{Berdasarkan Pendidikan Terakhir Responden}

Dari jumlah keseluruhan responden dengan jumlah 100 orang, unggul sebanyak 54\% dari 100 responden Studio Calista rata-rata berpendidikan SMA, selanjutnya responden berpendidikan diploma sebanyak 15\%, responden 
berpendidikan sarjana sebanyak 24\%, dan responden berpendidikan magister sebanyak 7\%. Dari semua data yang diperoleh tersebut dapat disimpulkan dan dilihat bahwa segmen pasar konsumen pada Studio Calista yaitu anak muda dengan usia 17-19 tahun. Hal ini sesuai dengan data di lapangan, dilihat dari tingkat pendidikan SMA yang lebih dominan berfoto, dengan alasan bahwa usia 17-19 tahun dapat dikategorikan anak muda atau sederajat dengan pendidikan SMA.

\section{Uji Asumsi Klasik}

\section{Uji Normalitas}

Tabel 3. Hasil Uji Normalitas

One-Sample Kolmogorov-Smirnov Test

\begin{tabular}{lll}
\hline & & $\begin{array}{l}\text { Unstandardized } \\
\text { Residual }\end{array}$ \\
\hline $\mathrm{N}$ & & 100 \\
Normal Parameters ${ }^{a, b}$ & Mean & .0000000 \\
& Std. Deviation & .87269497 \\
Most Extreme Differences & Absolute & .061 \\
& Positive & .048 \\
& Negative & -.061 \\
Test Statistic & & .061 \\
Asymp. Sig. (2-tailed) & & $.200^{\mathrm{c}, \mathrm{d}}$ \\
\hline
\end{tabular}

Sumber: SPSS 22, data diolah.

Berdasarkan hasil uji normalitas pada tabel 3 di atas, menunjukkan nilai Asymp Sig (2-tailed) sebesar 0,200. Hal ini menunjukkan bahwa nilai Asymp Sig (2-tailed) di atas 0,05 maka dapat disimpulkan bahwa data yang digunakan dalam penelitian ini berdistribusi normal.

\section{Uji Multikolinearitas}

Tabel 4. Uji Multikolinearitas

Coefficients $^{a}$

\begin{tabular}{|c|c|c|c|c|c|c|c|}
\hline \multirow[t]{2}{*}{ Model } & \multicolumn{2}{|c|}{$\begin{array}{c}\text { Unstandardized } \\
\text { Coefficients }\end{array}$} & \multirow{2}{*}{$\begin{array}{c}\begin{array}{c}\text { Standardized } \\
\text { Coefficients }\end{array} \\
\text { Beta }\end{array}$} & \multirow[b]{2}{*}{$\mathrm{T}$} & \multirow[b]{2}{*}{ Sig. } & \multicolumn{2}{|c|}{ Collinearity Statistics } \\
\hline & B & $\begin{array}{c}\text { Std. } \\
\text { Error }\end{array}$ & & & & Tolerance & VIF \\
\hline 1. (Constant $)$ & 1,610 & 1,085 & & 1,483 & 0,141 & & \\
\hline $\begin{array}{l}\text { Kualitas } \\
\text { Produk }\end{array}$ & 0,368 & 0,035 & 0,747 & 10,568 & 0,000 & 0,682 & 1,466 \\
\hline $\begin{array}{l}\text { Persepsi } \\
\text { Harga }\end{array}$ & 0,086 & 0,052 & 0,116 & 1.642 & 0,104 & 0,682 & 1,466 \\
\hline
\end{tabular}


Berdasarkan tabel 4 di atas, pengujian secara multikolinearitas terhadap data yang digunakan sebagaimana yang ditampilkan pada hasil uji regresi menjelaskan bahwa regresi antara variabel bebas yaitu variabel kualitas produk, variabel persepsi harga terhadap kepuasan konsumen tidak terjadi multikolinearitas, di mana nilai VIF pada variabel kualitas produk sebesar 1,466 dan variabel persepsi harga sebesar 1,466 sedangkan nilai toleransi pada variabel kualitas produk sebesar 68,2\% dan persepsi harga sebesar $68,2 \%$.

\section{Uji Heteroskedastisitas}

Pengujian heteroskedastisitas bertujuan untuk menguji apakah dalam model regresi terjadi ketidaksamaan varian dari residual satu pengamatan ke pengamatan lainnya. Model regresi yang baik adalah tidak terjadi heteroskedastisitas. Jika variabel independen tidak signifikan secara statistik dan tidak memengaruhi variabel dependen maka, ada indikasi tidak terjadi heteroskedastisitas. Berikut ini adalah hasil uji heteroskedastisitas pada penelitian ini.

\section{Tabel 5. Hasil Uji Heteroskedastisitas}

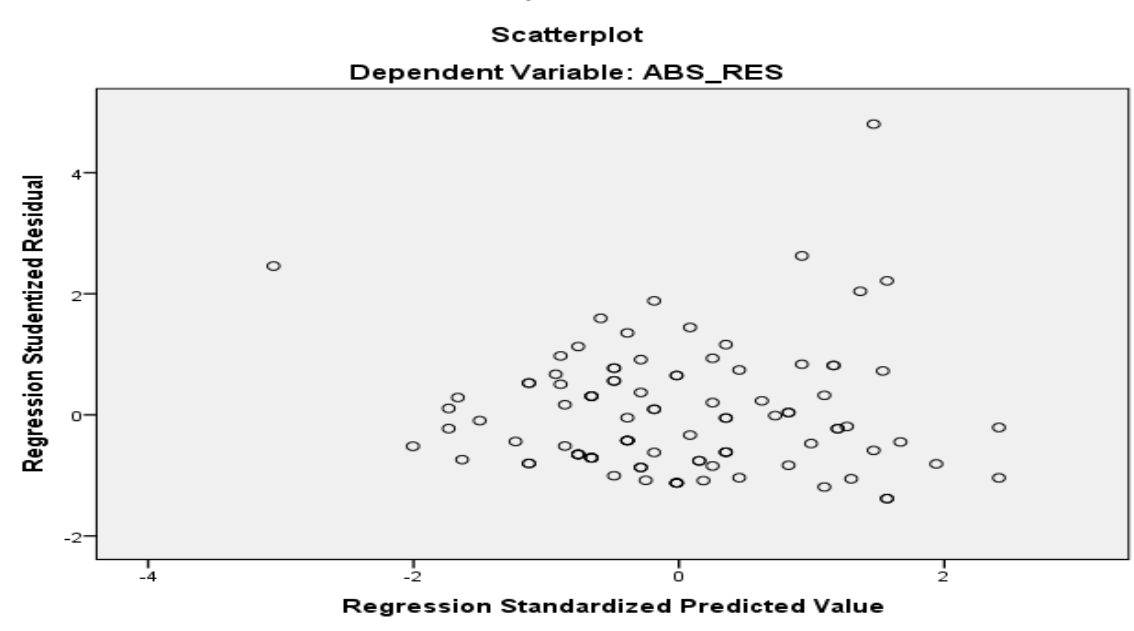

Berdasarkan tabel 5 di atas, dari hasil uji heteroskedastisitas menggunakan Scatterplot, menunjukkan tidak terjadi heteroskedastisitas, pada gambar di atas terlihat data sudah menyebar dengan acak dan tidak membentuk dengan pola yang jelas serta sudah tersebar baik di atas maupun di bawah. Model ini sudah terbebas dari gejala heteroskedastisitas sehingga layak untuk dipakai sebagai prediksi variabel dependen berdasarkan masukan variabel independen.

\section{Analisis Regresi Linear Berganda}

Analisis yang dilakukan adalah untuk mengukur besarnya pengaruh variabel bebas terhadap variabel terikat. Perhitungan analisis regresi mengunakan SPSS 22. Adapun model kelayakan regresi linear didasarkan pada hal-hal berikut: 


\section{Dependent Variable: Kepuasan Konsumen}

Hasil regresi menghasilkan persamaan sebagai berikut:

$\mathrm{Y}=1,610+0,368(\mathrm{X} 1)+0,086(\mathrm{X} 2)+\mathrm{e}$

Di mana persamaan regresi tersebut mempunyai makna sebagai berikut:

1. Konstanta $(\mathrm{a})=1,610$

Ketika variabel kualitas produk, persepsi harga sebesar 0 maka kepuasan konsumen bernilai sebesar 1,610.

2. Koefisien kualitas produk (X1) sebesar 36,8

Ketika variabel kualitas produk mengalami peningkatan sebesar satu satuan (\%) dan variabel persepsi harga dianggap tetap nilainya maka kepuasan konsumen nilainya meningkat sebesar $36,8 \%$. Hal tersebut menunjukkan bahwa variabel kualitas produk berpengaruh positif terhadap kepuasan konsumen.

3. Koefisien persepsi harga (X2) sebesar 8,6

Ketika variabel persepsi harga produk mengalami peningkatan sebesar satu satuan (\%) dan variabel kualitas produk dianggap tetap nilainya maka kepuasan konsumen nilainya meningkat sebesar 8,6\%. Hal tersebut menunjukkan bahwa variabel persepsi harga berpengaruh positif terhadap kepuasan konsumen dan tidak signifikan.

\section{Pengujian Hipotesis}

\section{Uji T (Parsial)}

Pengujian ini bertujuan untuk menguji model regresi variabel independen (kualitas produk dan persepsi harga) secara parsial berpengaruh signifikan, atau tidak terhadap variabel dependen (kepuasan konsumen) dengan tingkat signifikan $a=5 \%$ secara parsial berikut ini hasil pengujian hipotesis uji $t$.

Berdasarkan tabel bahwa hasil perhitungan koefisien regresi dengan uji t adalah berikut.

1. Hipotesis pertama, kualitas produk terhadap kepuasan konsumen. Pengujian signifikan mengetahui kualitas produk terhadap kepuasan konsumen, diperoleh nilai t-hitung 10,568 dan signifikan sebesar 0,000. Hal tersebut menunjukkan nilai signifikan $0,000<0,05$ dan nilai $\mathrm{t}$-tabel $=\mathrm{t}(\mathrm{a} / 2 ; \mathrm{n}-\mathrm{k}-1=\mathrm{t}$ $(0,05 / 2 ; 100-2-1=(0,025 ; 97)=1,98472$.

Berarti nilai t-hitung lebih besar dari t-tabel $(10,568>1,98472)$, maka dikatakan bahwa kualitas produk berpengaruh terhadap kepuasan konsumen. Dengan menggunakan batas 0,05 nilai signifikansi tersebut lebih besar dari taraf 5\% yang berarti Ho ditolak dan Ha diterima. Dengan demikian, hipotesis pertama diterima artinya terdapat pengaruh positif yang signifikan dari (X1) kualitas produk terhadap kepuasan konsumen (Y). 
2. Hipotesis kedua, persepsi harga terhadap kepuasan konsumen. Pengujian signifikan mengetahui persepsi harga terhadap kepuasan konsumen, nilai thitung 1,642 dan nilai signifikan sebesar 0,104. Hal tersebut menunjukkan nilai signifikansi $0,104>0,05$ dan nilai $\mathrm{t}$-tabel $=\mathrm{t}(\mathrm{a} / 2 ; \mathrm{n}-\mathrm{k}-1=\mathrm{t}(0,05 / 2 ; 100$ $2-1=(0,025 ; 97)=1,98472$. Berarti nilai t-hitung lebih besar dari t-tabel $(1,642<1,98472)$.

Maka dikatakan bahwa persepsi harga tersebut lebih kecil dari taraf 5\% yang berarti Ho diterima dan Ha ditolak. Dengan demikian hipotesis kedua penelitian ini tidak terbukti, itu artinya, tidak berpengaruh tetapi, dari persepsi harga (X2) terhadap kepuasan konsumen, tidak signifikan $0,104>0,05$. Alasannya, karena persepsi harga terdiri dari variabel harga moneter, non-moneter apabila kualitas produk memiliki kualitas yang bagus maka, konsumen tidak melihat persepsi harga (moneter dan non-moneter), di mana dalam harga konsumen tidak mempermasalahkan dengan alasan kualitas produk dan memenuhi keinginan/kebutuhan konsumen. Salah satunya alasan kosumen tidak mempermasalahkan kualitas produk yaitu, dilihat dari tingkat pekerjaan/pendapatan konsumen, tingkat pendidikan semakin tinggi, tingkat pendidikan semakin dewasa, dan semakin matang cara berpikir, sehingga konsumen sudah mengetahui apabila kualitas suatu produk bagus dan dapat memuaskan keinginan konsumen maka harga yang bagus tentunya dapat memuaskan keinginan konsumen, maka harga yang ditawarkan sudah sesuai dengan kualitas produk yang didapat.

\section{Uji Statistik}

Uji F

Pengujian hipotesis secara keseluruhan (simultan) terhadap variabel dependen dan independen adalah sebagai berikut:

Tabel 6. Hasil Uji secara Simultan

\begin{tabular}{llccccc}
\multicolumn{7}{c}{ ANOVA $^{\text {a }}$} \\
\hline \multirow{2}{*}{ Model } & Sum of & Df & Mean & \multirow{2}{*}{ F } & Sig. \\
\hline Segression & 152,642 & 2 & 76,321 & 98,187 & $0,000^{\mathrm{b}}$ \\
& Residual & 75,398 & 97 & 0,777 & & \\
& Resial & 228,040 & 99 & & & \\
\hline
\end{tabular}

a. Dependent Variable: Kepuasan Konsumen.

b. Predictors: (Constant), Persepsi Harga, Kualitas Produk.

Tabel 6 menunjukkan bahwa nilai F-statistik sebesar 98,187 dan tingkat signifikansi 0,000 di mana dengan signifikan $\mathrm{F}<5 \%(0,000<0,05)$ maka Ho ditolak. Hal ini menunjukkan bahwa secara simultan variabel kualitas produk dan persepsi harga secara bersama-sama berpengaruh signifikan terhadap variabel kepuasan konsumen. 


\section{HASIL DAN PEMBAHASAN}

\section{Pembahasan Pengaruh Kualitas Produk Terhadap Kepuasan Konsumen}

Pengaruh kualitas produk dan persepsi harga terhadap kepuasan konsumen Studio Calista, tidak terlepas dari demografi dan pengaruh terhadap berbagai perilaku untuk mencari kepuasan.

Hasil perhitungan secara statistik, nilai dari kualitas produk (X1) terhadap kepuasan konsumen (Y), diperoleh nilai t-hitung 10,568 dan signifikan sebesar 0,000 . Hal ini menunjukkan nilai signifikan $0,000<0,05$ bahwa dapat dijelaskan persamaan regresi yang diperoleh pada variabel kualitas produk memiliki pengaruh positif dan signifikan terhadap kepuasan konsumen. Untuk memengaruhi kepuasan konsumen, di mana semakin bagus kualitas suatu produk maka konsumen akan semakin loyal terhadap produk tersebut. Hal tersebut dikarenakan konsumen merasakan banyak manfaat yang didapatkan melebihi harga yang dikeluarkan.

H1: kualitas produk memiliki pengaruh positif terhadap kepuasan konsumen. Hal ini membuktikan bahwa kualitas produk berpengaruh positif terhadap kepuasan konsumen. Kualitas produk (X1) terhadap kepuasan konsumen (Y) diperoleh nilai t-hitung 10,568 dan signifikan sebesar 0,000. Hal ini menunjukkan nilai signifikan $0,000<0,05$.

\section{Pembahasan Persepsi Harga Terhadap Kepuasan Konsumen}

Pengaruh persepsi harga (X2) terhadap kepuasan konsumen (Y) diperoleh nilai t-hitung 1,642 dan tingkat signifikan 0,104 hal ini menunjukkan nilai signifikan 0,104>0,05 (tidak signifikan). Hasil tersebut membuktikan bahwa variabel persepsi harga berpengaruh positif terhadap kepuasan konsumen dan tidak signifikan. Sedangkan persepsi harga tidak berpengaruh terhadap kepuasan konsumen dengan alasan bahwa sebenarnya apabila kualitas suatu produk tersebut baik maka konsumen tidak akan mempermasalahkan harga, salah satunya berhubungan dengan tingkat pendapatan/pekerjaan konsumen. Apabila dilihat dari tingkat pendidikan konsumen, jika pendidikan seseorang tinggi dan ingin membeli suatu produk, tentu sudah mengetahui bahwa harga suatu produk yang bagus sudah sesuai dengan harga yang ditawarkan. Dengan alasan bahwa konsumen tersebut sudah mengetahui bahwa kualitas produk itu bagus dan sesuai dengan harga yang diberikan.

$\mathrm{H} 2$ : persepsi harga memiliki pengaruh positif terhadap kepuasan konsumen dan tidak signifikan untuk mengetahui pengaruh persepsi harga (X2) terhadap kepuasan konsumen (Y) diperoleh nilai t-hitung 1,642 dan tingkat signifikan 0,104. Hal ini menunjukkan nilai signifikan $0,104>0,05$ (tidak signifikan) terhadap kepuasan konsumen. 


\section{KESIMPULAN}

Berdasarkan hasil penelitian dan pembahasan, maka dapat ditarik beberapa kesimpulan sebagai berikut:

a. Terdapat pengaruh positif kualitas produk terhadap kepuasan konsumen Studio Calista. Hal ini dibuktikan dari nilai t-hitung sebesar 10,568 dan signifikan sebesar 0,000. Data tersebut menunjukkan nilai signifikan $0,000<0,05$ dan nilai $\mathrm{t}$-tabel $=\mathrm{t}(\mathrm{a} / 2 ; \mathrm{n}-\mathrm{k}-1=\mathrm{t}(0,05 / 2 ; 100-2-1=(0,025 ; 97)=1,98472$. Berarti nilai $\mathrm{t}-$ hitung lebih besar dari t-tabel $(10,568>1,98472)$, maka dikatakan bahwa kualitas produk berpengaruh terhadap kepuasan konsumen.

b. Terdapat pengaruh positif persepsi harga tidak berpengaruh terhadap kepuasan konsumen. Hal ini dibuktikan dari nilai t-hitung sebesar 1,642 dan nilai signifikan sebesar 0,104. Hal tersebut menunjukkan nilai signifikansi $0,104>0,05$ dan nilai $\mathrm{t}$-tabel $=\mathrm{t}(\mathrm{a} / 2 ; \mathrm{n}-\mathrm{k}-1=\mathrm{t}(0,05 / 2 ; 100-2-1=(0,025 ; 97)=$ 1,98472. Berarti nilai t-hitung lebih besar dari t-tabel $(1,642<1,98472)$. Maka dikatakan bahwa persepsi harga tersebut lebih kecil dari taraf $5 \%$ yang berarti Ho diterima dan Ha ditolak. Dengan demikian hipotesis penelitian ini tidak terbukti, itu artinya tidak berpengaruh dari persepsi harga (X2) terhadap kepuasan konsumen tidak signifikan 0,104>0,05.

c. Kualitas produk dan persepsi harga berpengaruh positif dan signifikan terhadap kepuasan konsumen Studio Calista. Hal tersebut ditunjukkan dari hasil analisis yaitu nilai $\mathrm{F}$ hitung 98,187 dengan nilai signifikan sebesar 0,000 kurang dari 5\% $(0,000<0,050)$. Dengan demikian dapat disimpulkan bahwa kualitas produk berpengaruh terhadap kepuasan konsumen sedangkan persepsi harga memiliki perbedaan yang signifikan dan tidak berpengaruh terhadap kepuasan konsumen.

\section{SARAN}

Berdasarkan hasil penelitian yang telah dilakukan, serta dari pembahasan dan kesimpulan yang diperoleh, maka saran yang diberikan yaitu sebagai berikut: bagi Studio Calista, perlu memberikan nilai lebih atas jasa dan produk yang dihasilkan untuk memberikan kepuasan konsumen. Salah satunya dengan menyediakan produk yang sedang populer di kalangan masyarakat. Dengan adanya foto produk yang bagus dapat menarik konsumen untuk membeli produk yang telah dipasarkan melalui bentuk foto yang terampil.

\section{KEPUSTAKAAN}

Amstrong, K. \&. (2001). Prinsip-Prinsip Pemasaran. Jakarta: Erlangga.

Budiyanto Arif. (2018). Pengaruh Persepsi Harga, Kualitas Layanan dan Brand Image Terhadap Tingkat Kepuasan Konsumen (Di PT, Yerry Primatam Husindo) Volume 1 No. 13.

Day. (1984). Journal of Marketing Research. Volume 25 No 2. 
Garvin, D. A. (1987). The Arr and Science of Business Management. New York Publishing.

Giardo Perinadi Putra, Zainul. Arifin, Sunarti. (2017). Pengaruh Kualitas Produk Terhadap Keputusan Pembelian dan Dampaknya Terhadap Kepuasan Konsumen" (Survei Mahasiswa Administrasi Bisnis Fakultas Ilmu Administrasi Angkatan 2013 dan 2014 Universitas Brawijaya Yang Melakukan Pembelian Paket Data Kampus). Volu.

Gozali., I. (2011). Aplikasi Analisis Multivariate dengan Program IBM SPSS 22. Semarang: Badan Penerbit Universitas Diponegoro.

Grace Marleen Wariki, Lisbeyth Mananeke. (2015). Pengaruh Bauran Promosi, Persepsi Harga dan Lokasi Terhadap Keputusan Pembelian dan Kepuasan Konsumen Pada Perumahan Tamansari Metropolitan Manado. Jurnal Bauran Pemasaran Volime 3 No. 2 Juni.

Indrawati, Fenny. (2018). Pengaruh Kualitas Produk Terhadap Loyalitas Pelanggan dengan Kepuasan Pelanggan Sebagai Variabel Intervening di Tinjau Stasiun Surabaya. Jurnal Anggora Volume 62 .

Keller, K. D. (2009). Manajemen Pemasaran; jilid 1 edisi ke 13. Jakarta: Erlangga. Petrick. (2016). Journal of Air Transport Management Volume 52 No. 42-54.

Prabowo, Heriyanto dan Yulianeu. (2017). Pengaruh Analisis Harga, Kualitas Produk dan Kualitas Pelayanan Terhadap Kepercayaan Pelanggan dengan Keputusan Pembelian sebagai Variabel Intervening (Studi pada Rumah Fotografi Kudus). Jurnal Manajemen Volume 3 No. 3.

Rosa Lesmana, R. (2019). Pengaruh Kualitas Produk dan Kualitas Pelayanan Terhadap Kepuasan Konsumen PT. Radekatama Piranti Nusa. Jurnal Manajemen Pemasaran.

Setyo, Purnomo. Edwin. (2017). Pengaruh Kualitas Produk dan Harga Terhadap Kepuasan Konsumen. Best Autoworka Volume 1 No. 6 hlm. 55

Swasta., B. (2013). Manajemen Pemasaran Modern. Yogyakarta: Liberty.

Tjiptono, F. (1997). Strategi Pemasaran; edisi II. Yogyakarta.

Tjiptono, F. (2014). Pemasaran Jasa; edisi II. Yogyakarta.

Yanti, Febri. Azizah Karim. (2018). Pengaruh Kualitas Pelayanan Terhadap Kepuasan Konsumen pada Studio Ribka Foto Cabang Sekip di Palembang. Jurnal Ekonomi Global Masa Kini Volume 8 No.2. 